\title{
Theory and Practice in 'L'amante di Gramigna"
}

\section{Massimo Verdicchio}

The importance of the "abbozzo di racconto," as Verga calls the short story "L'amante di Gramigna," for an understanding of his poetics and brand of verismo would not seem to be in question. ${ }^{1}$ Verga himself stresses the theoretical importance of his tale by accompanying it with a letter to the editor in which he explains the objectives of the new art form, "nuova arte" (Verga 233). The letter, which has since been published as the theoretical preface to the story, spells out in the first paragraph Verga's idea of verismo and his claims to a conception of literature as a document of the drama of human passions.

Caro Farina, eccoti non un racconto, ma l'abbozzo di un racconto. Esso almeno avrà il merito di esser brevissimo, e di essere storico - un documento umano, come dicono oggi - interessante forse per te, e per tutti coloro che studiano nel gran libro del cuore. (Verga 230-31)

It comes as somewhat a surprise, therefore, to note that most critics in discussing questions of verismo and Verga's poetics always disregard the story and look elsewhere for works more representative of Verga's method. Giacomo Debenedetti, for instance, after discussing the letter to Farina turns to the story "Rosso Malpelo," also from Vita dei campi, to contrast Verga's theory of verismo with its literary practice (413 ff.). When "L'amante di Gramigna" is read as the literary exemplification of a theory of verismo, as in a recent study by Giorgio Bàrberi Squarotti, the result is a naturalistic, literal reading that does not go much beyond paraphrase. Bàrberi Squarotti believes that Verga's verismo amounts to a shift from a literary or metaphorical mode of representation to a naturalistic and literal one: "lo scrittore si defila, scompare dalla scena, dichiara l'abbandono della letteratura come la positiva esemplificazione di un discorso che è il fatto, senza bisogno che il lettore debba . . . cercarlo nell'inevitabile metaforicità della scrittura letteraria" (Squarotti 15). The summary is in order because one is dealing not so much with literature, which would require interpretation, as with real life documents that only need summing up.

The theoretical relevance of the letter has been similarly reduced. Verga's remarks, when they are taken seriously, are generally deemed to be applicable only in part to the short stories but not to the later and more mature novels. ${ }^{2}$ The major objection to the letter comes, once again, from Debenedetti who speaks of 
serious shortcomings in Verga's theoretical pronouncements, "(di) quel suo modo corto e un po' confuso, tutto insieme semplicistico e inceppato, di parlare per idee generali" (383). For Debenedetti, there is great discrepancy between the vague theoretical generalization stated in the letter and the short story. "Ma questi enunciati sono più tardivi, rimangono abbastanza generici, non collimano rigorosamente con la pratica, con l'operare del Verga artista" (384). Verga is the artist of verismo, not its theorist (the honour goes to Capuana) mainly because he has no reflex knowledge of his artistry and falls easily prey to generalizations:

perché nel Verga, personalmente, la consapevolezza della propria arte non riesce mai a dichiararsi del tutto, e in ogni caso è aliena dal pronunciarsi in modo esplicito. Quando il Verga vuol parlare in generale, casca nel generico o per lo meno in una involontaria ambiguità . . con le effettive opere d'arte. Il Verga sa fare, non sa dire quello che fa" (17, italics mine).

Between the theory and the literary practice there is a qualitative difference because the artist not only is not a theorist but not even his best critic, and is quite incapable of describing what he otherwise excels at.

Verga and his verismo have not fared much better in more recent criticism. In his important work on self-conscious narrative in Italian fiction, which claims to break away from traditional critical practice, Gregory Lucente chooses nonetheless "Rosso Malpelo" as exemplary of Verga's narrative style and brand of veri$s m o$, "because the novella was of distinctive import both for Vita dei campi and for the overall development of Verga's realist oeuvre" (69). The reasons for Lucente's choice do not stem entirely from theoretical considerations based on the novella but are dictated by tradition since, as he writes in a note, critics from Russo to Luperini have always looked to "Rosso Malpelo" as the story that most exemplifies Verga's brand of verismo:

Since Luigi Russo first described the story as "il racconto più organico" ... of Vita dei campi ... many other writers have characterized the novella as Verga's most unified, most important, or simply as his best. The importance of the story is further indicated by Romano Luperini's dedication of an entire monograph to it, Verga e le strutture narrative del realismo: Saggio su Rosso Malpelo . . . . (Lucente 348)

Luperini, in fact, considers this novella exemplary of the "stylistic and linguistic revolution" that marks a radical departure from Verga's early works, and even "Nedda," toward a poetics of verismo.

La rottura tra Nedda e Rosso Malpelo non sta nella tematica esistenziale dell'esclusione, che è comune ai due racconti, ma nella rivoluzione stilistica e linguistica che divide quella da questo e che presuppone un cambiamento radicale nella visione del mondo verghiana. . . . Il fatto è che tra Nedda e Rosso Malpelo c'è stata la scelta dell' impersonalità, l'adesione al verismo. (Luperini 43, my italics) 
According to Luperini, Verga's radical shift in poetics ("rovesciamento di poetica" 44), admirably exemplified in "Rosso Malpelo," consists in a new impersonality whereby the author no longer intervenes to defend his characters, as in "Nedda," but leaves it to the narrating voice: "le motivazioni del carattere del protagonista sono date dalla voce narrante e lo scrittore si guarda bene dall'intervenire a ristabilire la 'sua' verità" (45). The same occurs in I Malavoglia where Verga's judgement is similarly expressed by a chorus of characters: "nei Malavoglia la stessa scena sarebbe stata rappresentata proprio dal punto di vista delle "comari"' (45). In my analysis I shall argue just the opposite since the chorus of characters stands for the mystification that Verga is denouncing.

These critics' choice of novella to exemplify Verga's verismo is both acceptable and suspect. It is acceptable because, after all, as one of the novellas from Vita dei Campi, "Rosso Malpelo" is just as valid as any novella to demonstrate Verga's narrative method. It is suspect since the privileging of "Rosso Malpelo" is made, as Lucente emphasizes, on traditional grounds that the story is a complete and unified narrative. The risk inherent in this choice is that the novella becomes the recipient not so much of Verga's verismo as of our traditional ways of reading Verga. Our reading of the novella, as Luperini's comments demonstrate, tend to focus on the substance and meaning of the novella rather than on its process and dynamics, as Verga intimates. They focus on the "what" rather than the "how." The advantage in examining "L'amante di Gramigna" for an understanding of Verga's poetics does not lie just in the fact that the story exemplifies for its author his new narrative method but because it is a "bozzetto di storia," the sketch of a story. Its brief and bare outline makes it possible to determine quickly and accurately the modalities of Verga's new impersonal narrative which can be read in other stories and novels. This is the objective of my paper which will examine first Verga's letter to Farina and then the story in order to reassess their relevance for an understanding of Verga's poetics of verismo.

\section{The Theory}

In the letter to Farina, Verga writes that the prose sketch is not only brief but historical ("storico"). What Verga means is clarified by the phrase "un documento umano" by which he does not mean a factual account or an historical document. While the human document has its referent necessarily in historical fact, the source Verga alludes to is the great book of the heart ("nel gran libro del cuore"). Verga's appeal to Farina is not simply to an editor who may find his views interesting ("interessante forse per te"), but is made to a fellow writer who can understand what he means.

Verga has in mind an experience which is first of all literary and common to every writer who has read in "the great book of the heart" and knows the heart of man and his passions. Another name for this book is "literature" and, in this case, 
Italian literature, which since Dante's Vita Nuova, if not earlier, has always dealt with the predicament of human passions.

Il misterioso processo per cui le passioni si annodano, si intrecciano, maturano, si svolgono nel loro cammino sotterraneo, nei loro andirivieni che spesso sembrano contraddittori. (232)

Literature, from time immemorial, has always strived to understand and portray the mysterious process of human passions, how they are born, nurtured and develop. In connection with the subject of Love, which is the central passion of "L'amante di Gramigna," we could mention the love poetry of Guinizelli, Cavalcanti and Dante, to mention only a few examples from one period. The list, clearly, is endless and would include most literary works. Verga, in other words, wants to say that his objective is not different from that of his literary predecessors. The difference is in how he chooses to deal with this eternal subject and how he represents the mysterious workings of human passion.

Io te lo ripeterò così come l'ho raccolto pei viottoli dei campi, press'a poco colle medesime parole semplici e pittoresche della narrazione popolare. (232)

He intends to portray this process not from the omniscient point of view of an author but from the limited perspective of a bystander who, having heard the story at secondhand, recounts it in his own words, in the simple and picturesque language of country folk. Verga wants to give the reader a sense of immediacy, of being a participant in the action of the story, rather than being mediated by the words of explanation and commentary of the author "faccia a faccia col fatto nudo e schietto, senza stare a cercarlo fra le linee del libro, attraverso la lente dello scrittore" [232]).

Verga does not mean, however, that the reader as observer will be confronted with the events proper, as is so often thought, but with how others recount these events and what they say about them. The result is a mediated immediacy which does not allow events to be experienced directly as they are but always presents them distorted through others. The reader never quite experiences the historical event, which becomes secondary, only the mysterious process that moves the human heart and its passions. This process becomes the "true" event of the story and the one Verga's verismo aims to imitate and portray.

The narrated events, nonetheless, are still under the control of the writer. Verga reminds Farina that his approach to narrative is not very different from that of the many great works of literature, or "monumenti gloriosi." The difference, once again, is in the emphasis that Verga chooses to place on the narrative.

Noi rifacciamo il processo artistico al quale dobbiamo tanti monumenti gloriosi, con metodo diverso, più minuzioso e più intimo. Sacrifichiamo volentieri l'effetto dei fatti verso la catastrofe resa meno impreveduta, meno drammatica forse, ma non meno fatale. (232) 
Verga shifts his emphasis from the effects to the causes to focus on the mysterious process of the unfolding of passions and events. This critical stand is meant to be somewhat polemical toward the type of melodramatic literature popular at the time and in which the stress, instead, is on the surprising and dramatic finale. Like all those who take an interest in the study of the human heart, Verga focuses on the process which brings about the character's tragic demise, on the "legame oscuro tra cause ed effetti" (232). The tragic ending does not need elaboration since it is just as predictable as it is inevitable. By describing this process, Verga fulfills his role and duty as writer which is to teach the reader a lesson in the science of the human spirit ("la scienza del cuore umano" [233]). Once again, Verga's objectives are not very different from what other writers have set themselves. Dante's Commedia is one example that comes to mind.

Verga has been unjustly accused of looking forward to a future without literature, when "i fatti diversi," that is chronicles of everyday facts and occurrences, will take its place. Croce, for example, declared: "Queste idee sono chiaramente erronee" (Croce 19). Verga, however, meant something quite different.

Si arriverà mai a tal perfezionamento nello studio delle passioni, che diventerà inutile il proseguire in cotesto studio dell'uomo interiore? La scienza del cuore umano, che sarà il frutto della nuova arte, svilupperà talmente e così generalmente tutte le virtù dell'immaginazione, che nell'avvenire i soli romanzi che si scriveranno saranno $i$ fatti diversi? (233)

These declarations accompanied by question marks are more rhetorical than intended. The full realization of a science of the human heart does not rest solely with the author or with the new writers but with the reader. Only when readers will learn to read and understand the human heart as writers can, will literature become obsolete. The fact that Verga is asking the question implies that he is not very optimistic that it may occur any time soon. The answer to the question posed by Verga, therefore, is "no," and as added proof we could mention our own limited understanding of Verga's works as records of the human heart.

The last section of the letter is, perhaps, the most problematic. Here Verga raises the issue of the impersonality of the work of art and looks forward to a work of literature where the hand of the writer will be invisible and the work will seem to have sprung up naturally by itself without the help of the writer.

la mano dell' artista rimarrà assolutamente invisibile, allora [il romanzo] avrà l'impronta dell' avvenimento reale, l'opera d'arte sembrerà essersi fatta da sé, aver maturato ed esser sorta spontanea, come un fatto naturale, senza serbare alcun punto di contatto col suo autore, alcuna macchia del peccato d'origine. (233)

The passage has given rise to all sorts of speculation most of it negative because Verga's claim has seemed preposterous and outright false. Bàrberi Squarotti, for instance, regards the claim as a strategy to shirk from his authorial responsibili- 
ties, as a way of hiding from the reader (or the critic?) who will not be able to blame or criticize the author who, supposedly, is only representing facts:

e la strategia dello scrittore ... diviene allora davvero decisiva e arbitraria, nel momento in cui appare e rifiuta di dichiararsi complice degli eventi narrati e dei personaggi rappresentati, cioè si nasconde per dare a credere di non esserci più e il lettore non può quindi prendersela più con lui, che non c'è, ed è insensato prendersela con $\mathrm{i}$ fatti contenuti nella narrazione, dal momento che sono perfettamente "reali." (20)

The hypothesis justifies the subtitle of Bàrberi Squarotti's book, Le finzioni dietro il verismo, fictions which the critic aims to demystify and denounce. In my view, however, we are not dealing with any subtle stratagem to deceive or neutralize readers or critics. In any case, this would be an almost impossible task with critics like Bàrberi Squarotti. Rather, Verga's claim is based on a conception of the work of art which sees "coesione" between the "mysterious" process of the passions represented and the creative process which represents it. Since for Verga the two processes coincide, the claim of impersonality is not only understandable but inevitable. The first part of the quotation, which I omitted earlier, is as follows:

Quando nel romanzo l'affinità e la coesione di ogni sua parte sarà così completa, che il processo della creazione rimarrà un mistero, come lo svolgersi delle passioni umane, e l'armonia delle sue forme sarà così perfetta, la sincerità della sua realtà così evidente, il suo modo e la sua ragione di essere così necessari . . . . (233, italics mine)

The effect of placing the reader "face to face" with the event is made possible by a mode of representation where by the mysterious process represented coincides with the writing process. The reader/observer can easily ignore the fact that he is reading a novella or a novel because the language of the work is one and the same with the characters' language of passion. As our analysis of " $L$ 'amante di Gramigna" will show, the mystery of human passions represented by Verga is the result of a process which, in origin, is independent of the characters and events narrated, as well as of the writing process which represents it and exemplifies it. Verga's objective to place readers in a situation where they are listening to someone recounting or experiencing an event, has to be taken more seriously than it is usually. For Verga it is not simply a literary device but an essential aspect of his poetics which closely concerns the representation of the mysterious process of human passions. Failure to understand this point has led critics like Bàrberi Squarotti to believe that the "original sin" meant by Verga is literature which the author would gladly exchange for some type of automatic writing.

Il "peccato d'origine" è, evidentemente, la letteratura: dal romanzo moderno dovrà essere del tutto cancellata a favore del fatto così com'è, e il "mistero" della 
scrittura presso che automatica potrà così pareggiare il conto con il mistero delle passioni umane. (Squarotti 14-15)

The "original sin" consists in the fact that the work of art is, after all, a work of fiction and, as such, liable to be misunderstood and taken to be what it is not, namely, a fiction. In other words, it is liable to be misrepresented and not taken as a representation of true events. This is the risk of any literary work when it is taken to be nothing more than a work of fiction. Hence the notion of "original sin" which condemns fiction to always being fiction even when it makes the effort of portraying the "real" ("i fatti diversi"). For Verga's verismo, therefore, it is not so much literature which is an impediment to understanding as much as the readers' understanding which, despite the author's intentions, will always regard his works as fiction rather than as fictitious equivalents of "real" life situations. As I indicated earlier, this is the greatest barrier to the evolution of literature from fiction to "i fatti diversi" envisaged, if not hoped for, by Verga.

To sum up the theoretical "sense" of Verga's letter to Farina, we could say that Verga's new kind of writing seeks to represent the historical reality of human events with the stylistic efficacy that would give readers the illusion of having been there and having heard it for the first time. However, he is not interested in representing facts, history or reality, but in drawing the readers'attention to the mysterious and baffling logic of human passions which inexorably and inevitably leads men to tragedy. This process and the process of writing are one and the same. Verga will not tell readers what happens in the story in so many words; rather, he confronts them with events and lets them make up their own minds. In so doing he achieves that objectivity and impersonality associated with verismo that allows readers to be observers of "real" events rather than readers of a story about the event. Verga's aim is not, as Bàrberi Squarotti suggests, to negate literature in favour of some kind of automatic writing or even to shirk from his responsibilities as a writer. The aim of his "new art" is to remind readers that what is being represented is not a product of the author's imagination (although the story and its characters are his invention) but something completely independent of his will and fiction. This is the theory that Verga's sketches for Farina and which we should find translated in narrative form in "L'amante di Gramigna."

\section{The Story}

The title of the story is itself telling because the name of the outlaw "Gramigna" already alludes to that "mysterious" process of human passions that Verga refers to in the letter and which constitutes the focus of the novella. ${ }^{3}$ The name "Gramigna" literally means "mala pianta" (weed, evil plant) and has all the connotations of evil: "un brigante, certo Gramigna, se non erro, un nome maledetto come l'erba che lo porta" (Verga 233). In the story, Gramigna functions as an evil weed destroying everything in his path. He creates fear and terror in the countryside 
and threatens to destroy the local harvest because the landowners and the farmers are too afraid to work in the fields.

Per giunta si approssimava il tempo delle messi, tutta la raccolta dell'annata in man di Dio, ché i proprietari non s'arrischiavano a uscir del paese pel timore di Gramigna. (234)

Compare Finu, for example, a young and wealthy landowner is afraid that Gramigna might set fire to his harvest:

nel tornare ogni sera dalla campagna, lasciava la mula all'uscio della Peppa, e veniva a dirle che i seminati erano un incanto, se Gramigna non vi appiccava fuoco. (235, italics mine)

Most important, Gramigna destroys Compare Finu's future marriage to Peppa which was to be celebrated soon after the harvest.

Compare Finu not only owned many lands ("aveva terre al sole e una mula baia nella stalla"), but was young, strong and handsome, "un giovanotto grande e bello come il sole" (235). He is the best catch in town. "Le comari . . . avevano invidiato a Peppa il seminato prosperoso, la mula baia, e il bel giovanotto che portava lo stendardo di Santa Margherita senza piegar le reni" (236). He is everything a woman might wish for in a husband but Peppa decides, mysteriously, to break off her promised marriage to him and to run off to live with Gramigna. "Ma Peppa un bel giorno gli disse: - La vostra mula lasciatela stare, perché non voglio maritarmi - " (235).

This is the central concern of the story: Why Peppa leaves the man to whom she is betrothed to seek out a bandit she has never even seen? How could Peppa, "una delle piu belle ragazze di Licodia" (234), degenerate to the point of becoming, at the end of the story, "lo strofinacciolo della caserma" (239), a servant to the soldiers who had captured Gramigna? These are the questions that any bystander would ask when hearing the story "faccia a faccia col fatto nudo e schietto," or as they hear it related from a passer-by on a country road, or as they read it in a newspaper as one of the many "fatti diversi." Verga's concern in narrating the story of Peppa and Gramigna is to answer these questions by providing the readers with an insight into the mysterious process of human passions and to provide them with an understanding ("scienza") of the human heart.

Peppa's infatuation with Gramigna is explained gradually and indirectly. Although she has never set eyes on him, the talk she "hears" about his prowess and accomplishments makes her believe he was a "real" man and she gradually falls in love with that image.

Che è, che non è, Peppa s'era scaldata la testa per Gramigna, senza conoscerlo neppure. Quello sì che era un uomo! - Che ne sai? - Dove 1'hai visto? - Nulla. (235, my italics) 
The more Peppa hears stories about Gramigna's accomplishments the more she becomes infatuated with him and the more she desires him.

Però ella seguitava a dire che non lo conosceva neanche di vista quel cristiano; ma invece pensava sempre a lui, lo vedeva in sogno, la notte, e alla mattina si levava colle labbra arse, assetata anch'essa, come lui. (236)

Her mother's attempts to prevent her from hearing more about him and to dissuade her from her blind passion fail.

Allora la vecchia la chiuse in casa, perché non sentisse più parlare di Gramigna, e tappò tutte le fessure dell'uscio con immagini di santi. Peppa ascoltava quello che dicevano nella strada, dietro le immagini benedette, e si faceva pallida e rossa, come se il diavolo le soffiasse tutto l'inferno nella faccia. (236, italics mine)

The origin of Peppa's passion for Gramigna is in the stories she hears about him related by passers-by and by those around her. These stories prey on the young woman's imagination by creating an idealized image of Gramigna as a "real man" in whom she blindly believes and comes to desire.

It is clear from the story that the people who talk about Gramigna and his heroics have never seen him. What they know and relate is what they have "heard" from someone else. In other words, what Peppa "hears" about Gramigna, as well as what we readers know and read about him, is what people in the countryside have heard and, in their turn, have repeated to others. These stories, therefore, do not narrate real events but are the grossly exaggerated tales that people spin about people and events they know nothing about, which is why they invent them. The fact that Gramigna is still on the loose and not much else is known about him is sufficient to stimulate people's imaginations to invent and exaggerate details about a Gramigna with superhuman qualities. These fictions transform Gramigna from a petty bandit and a fugitive from justice into a larger-than-life hero, feared, admired and loved. The following description, which readers usually read as a true account of actual events, is in fact the exaggerated account of what people invent about Gramigna and which Peppa and the reader "hear."

Carabinieri, soldati, e militi a cavallo, lo inseguivano da due mesi, senza esser riusciti a mettergli le unghie addosso: era solo, ma valeva per dieci, e la mala pianta minacciava di moltiplicarsi . . . . Il prefetto fece chiamare tutti quei signori della questura, dei carabinieri, dei compagni d'armi, e subito in moto pattuglie, squadriglie, vedette per ogni fossato, e dietro ogni muricciolo: se lo cacciavano dinanzi come una mala bestia per tutta una provincia, di giorno di notte, a piedi, a cavallo, col telegrafo. Gramigna sgusciava loro di mano, o rispondeva a schioppettate, se gli camminavano un po' troppo sulle calcagna. Nelle campagne, nei villaggi, per le fattorie, sotto le frasche delle osterie, nei luoghi di ritrovo, non si parlava altro che di lui, di Gramigna, di quella caccia accanita, di quella fuga disperata. I cavalli dei carabinieri cascavano stanchi morti; i compagni d'armi si buttavano rifiniti per terra, in tutte le stalle; le pattuglie dormivano all'impiedi: egli solo, 
Gramigna, non era stanco mai, non dormiva mai, combatteva sempre, s'arrampicava sui precipizi, strisciava fra le messi, correva carponi nel folto dei fichidindia, sgattajolava come un lupo nel letto asciutto dei torrenti. Per duecento miglia all'intorno, correva la leggenda delle sue gesta, del suo coraggio, della sua forza, di quella lotta disperata, lui solo contro mille, stanco affamato, arso dalla sete, nella pianura immensa, arsa, sotto il sole di giugno. (234, italics mine)

This account of Gramigna does not correspond to real events but reproduces only the exaggerated version fabricated by people's fears, ignorance and vivid imaginations. This fiction takes the place of reality and becomes for those who create it and keep it alive the only reality. This is the "reality" Peppa falls in love with and the fiction that Verga claims is independent of the author who represents it, and rightly so.

The exaggerated tales that transform Gramigna into a hero inflame Peppa's imagination and arouse her passion. As a young and impressionable girl, perhaps betrothed to someone she does not love, she readily believes them as if they were real. In her mind, the prospect of being married to the wealthiest and most handsome man in town - Verga purposedly exaggerates the physical attributes and material wealth of Compare Finu - is not as exciting and thrilling as a life with a man who risks his life everyday in combat against hundreds of soldiers and whose adventurous life is in her eyes a welcome relief from the humdrum existence in which she lives and will live as Compare Finu's wife. It comes as no surprise, therefore, that Gramigna appears to her as more of a man and more of an object of desire than the man she is soon to wed.

Verga explains Gramigna's transformation from unknown criminal to hero as the terror, or evil, of fame: "il terrore della sua fama." Verga wants to allude not only to the fear that Gramigna instills in those who spread rumors about his "deeds," but also to the destruction he causes in his wake such as the break up of Peppa's engagement to Compare Finu and her eventual tragic end. The two, in fact, are but aspects of the same process since the terror that Gramigna creates in others is the result of the stories people relate about him.

To appreciate what is really going on in this short but complete sketch, we must distinguish between what Verga tells us of Gramigna, the character, from Gramigna, the terror that fame has created. The distinction entails a differentiation between Verga the author and Verga the observer, from whose point of view the story is partly told, and who poses as any bystander who hears the story of Gramigna and Peppa "pei viottoli dei campi." While the presence of the author marks the inevitable "peccato d'origine" of which Verga speaks in the letter to Farina, it is also the necessary presence which allows the reader to differentiate fact from fiction, which usually are identical in a naturalistic story, and determine the cause of Peppa's afflictions and the mysterious workings of the human heart.

The presence of Verga the writer undermines what is being stated by Verga the observer and denounces the discrepancy between the "real" Gramigna from the larger-than-life hero that fame has created. At the beginning of the tale, Verga 
goes out of his way to emphasize that Gramigna was virtually an unknown, "un brigante, certo Gramigna, se non erro" (233, italics mine). Verga wants to dispel any doubt the reader may have that Gramigna is the great bandit people are making him out to be. This is also confirmed by the episode where Peppa meets up with the bandit for the first time. We see him, then, for what he really is, a ruthless, unfeeling and despicable man who takes advantage of Peppa's infatuation to serve his own selfish ends (237).

The key insight the reader gains from an awareness of the discrepancy between the two Gramignas is what Verga calls the "terror of fame." He describes the mysterious process whereby an unknown outlaw becomes, in the people's imagination, a feared bandit capable of standing up alone against a thousand men. By virtue of this process, the initial story of Gramigna, a lone and unknown bandit, "grows" and multiplies ("era solo, ma valeva per dieci") like weeds in the mouths of those who spread stories about him. Likewise, the number of soldiers sent after him multiplies, and this only increases his prowess as he is always able to elude them and defend himself against hundreds. Similarly, talk of Gramigna multiplies everywhere ("non si parlava d'altro che di lui"). He becomes the talk of the town and people constantly speak, or invent stories, about him. This process escalates to the point that the rumours attribute to him almost supernatural powers. He is always fighting and he is never tired, whereas those in pursuit are made to seem inept and fatigued. He becomes the legendary hero ("la leggenda delle sue gesta"), strong and courageous, and always successful.

Gramigna's power is the power of "gramigna," of "mala pianta," or, which is the same, the power of fame since, as I indicated earlier, "fama" and "mala pianta" are words for the same thing. The story is based on and develops from this pun until it has distorted the characters' sense of reality and destroyed all that is good in its path. The process describes the "semplice fatto umano" that for Verga explains the "misterioso processo" that stirs human passions. This is the process whereby the hyperbolic and exaggerated language of hearsay excites the imaginations and passions of a young woman and (mis)leads her into believing in the reality of a fiction that eventually destroys her. For the nature of this mysterious process is such that no one and nothing can stop it once it has been set in motion. Even the confrontation with the real Gramigna is unable to open Peppa's eyes. Even iong after his capture, and the humiliations she suffers for him, Peppa remains faithful to the image of the man she loves despite the fact that from the moment she meets him everything contradicts it.

The mysterious unfolding of human passions and the fictitious language of hearsay, which triggers it, are not only mirror images of the same process but they are also at one with the creative process. This identity between the language of hearsay, the language of passion and the language of the story justifies Verga's claim of objectivity. The key term common to all these processes, which in the story is differently rendered as "gramigna," "mala pianta," "fama," is language, figural or metaphorical language, as the initial pun suggests: the language of 
passion in Peppa's case, the language of fear for the townspeople, and the descriptive language of the story which imitates their exaggerated tales. In each case we are dealing with a process that only apparently is within the control of the speaker. This is clearly the case with the language of fame which easily moves beyond the meaning intended by the speakers transforming and distorting the reality which they believe they are describing.

Nelle campagne, nei villaggi, per le fattorie, sotto le frasche delle osterie, nei luoghi di ritrovo, non si parlava d'altro che di lui, di gramigna, di quella caccia accanita, di quella fuga disperata. (234, italics mine)

It is a language that does not state things as they are but distorts the reality of things making them appear different or, as in Peppa's case, more appealing than they are. The language of fame or hearsay is not rooted in reality but takes the real as its starting point inventing its story as it goes independently of the original meaning which it distorts and does violence to. For, as it is clear from the story and its title name "mala pianta," this language is ultimately destructive. When this language is allowed to take the place of the real and is believed to be real, as in Peppa's case, it blinds the character to a reality from which she becomes increasingly severed and precipitates her toward her inevitable tragic fate. What in the story is called the terror of fame is really the terror of language.

Similarly, the exaggerated tales of the townspeople about Gramigna's extraordinary feats, which are symptomatic of their fears and their ignorance of what is really going on, multiply as their tales become more terrifying and threatening. The terror of their tales generates more tales to account for or dispel those fears, and so on. In both cases, the real threat is not Gramigna but this language, these tales, which people invent and which now come back to haunt them. And in both cases the process is destructive. At the level of textual representation, the figural or tropological equivalent to this process is the trope of personification. Gramigna, as I indicated, is a pun, a play on words, to personify evil, or better, the destructive process of evil, as exemplified by the destructive growth of weeds which, growing rampant in a field destroy all vegetation. Gramigna, as the personification of this evil, can be said to allegorize the proliferation of figural language from the initial pun to ever more terrifying and threatening transformations, distorting and doing violence to our own sense of reality. As in the story of Frankenstein, the man-created monster that goes out of control until it destroys everything in its path including its creator, in Verga the monster "Gramigna" is this figural language which creates havoc amongst the characters which feed it and nourish it until it has destroyed the very people that keep it alive. Peppa is not the only victim. Besides her and Compare Finu, Peppa's mother dies heartbroken for the shame her daughter has brought on her house and family. The reader is also another victim. Reading this tale as just a simple tale of a woman who falls in love with a bandit, the reader's sense of what is really going on is 
distorted and violated. But, then, this is one of the objectives Verga's verismo hoped to achieve.

The same can be said of the author. Verga has no more control over this language than the townspeople or Peppa. In representing the simple and picturesque words of popular narrative, "press'a poco colle medesime parole semplici e pittoresche della narrazione popolare" (232), Verga is equally caught within this process as the others are and can only represent it as it unravels. The inevitability of this process, to which even the author must abide, ensures, the impersonality and objectivity that Verga claimed in the letter to Farina. From this perspective, one can easily see how Verga can state that the work of art will seem to have been made by itself ("essersi fatta da sé") and to have arisen spontaneously "as a natural fact."

The difference between Verga and his characters lies precisely in the awareness of the constitutive figural nature of this process. Verga calls it "il peccato d'origine," the original sin which, in theory, discriminates between the literary event of the story from everyday events, the "fatti diversi." At the narrative level, however, it is exemplified as an awareness of the constitutive fictional or narratological nature of the process which enables the reader to become aware of the mystification inherent in the process. Through this process, the reader can gain an insight into the depth and complexity of the human heart, of the mysterious process of human passions that inevitably lead man to catastrophe. Verga imitates the arbitrary and mysterious process that drives men and women to their fate and denounces its inherent fictitious and figural nature by calling attention to it and paving the way towards a deeper and greater understanding of the human psyche and its passions.

Our analysis of "L'amante di Gramigna" proves that there is no discrepancy between the story and Verga's letter to Farina, between the theory and the narrative practice. The prose sketch stands as the "perfect" narrative equivalent to the theoretical statement. It illustrates in a narrative, or allegorical mode, what the author had already stated theoretically. Contrary to traditional opinion, Verga can be said to be very much the theorist of his own brand of verismo and to possess a very clear understanding of his work. It could not be otherwise. It would be impossible for a writer of Verga's stature not to possess a theoretical understanding of nis own literary constructs. We could go one step further and say that Verga is a theorist of verismo because he is a great writer of the genre, or at least of his own genre of verismo. Capuana may be a better theorist of verismo, as Debenedetti claims, but since he is not reputed to be as great a writer as Verga, his understanding of verismo is bound to be theoretical and abstract making it highly doubtful that he would be capable of probing the depths of Verga's prose.

It goes without saying that what has been said of "L'amante di Gramigna" applies not only to Verga's other stories but also to "Rosso Malpelo." All of them can be said to be allegories of Verga's theory of verismo expounded in the letter to Farina. It would not be difficult to show, for example, that, like Peppa's, Ros- 
so's tragic fate is the result of the misnomer "malpelo" and follows the same destructive path as Gramigna's "mala pianta." The townfolks' arbitrary and initially innocent naming of Rosso as "malpelo" condemns the boy to an image of himself he feels he must live up to, regardless of his true nature, until the process (generated by the name and the reputation) brings about his demise. Rosso, like Peppa, is a victim of people's "hearsay" about him and, like Peppa, he is caught in a process he cannot control but can only resign himself to and accept.

A similar process is at work in the novels and clearly in I Malavoglia where the main characters have equally been branded with a misnomer that can't wait to be fulfilled. Although they are a hard-working family, they are known as "I malavoglia," as lazy and indolent. The mysterious process of man's passions resurfaces in the Malavoglia family's desire to improve their lot, to have a better and more prosperous future, "la vaga bramosia dell'ignoto, l'accorgersi che non si sta bene, o che si potrebbe stare meglio" (Verga 177). Once this desire is acted upon and translated into reality, by purchasing the rotten lupines, a process similar to the one described in "L'amante di Gramigna" is set into motion with no hope of arresting it until the entire family goes to ruin and the name "malavoglia" becomes a fit description of at least one of their members.

In the introduction to his novel, Verga alludes to this process as "fiumana." The term describes not only the mysterious process in which the main characters of I Malavoglia are caught but also the fatal journey of humanity that Verga, with full irony, calls man's progress:

Il cammino fatale, incessante, spesso faticoso e febbrile che segue 1'umanità per raggiungere la conquista del progresso .... (Verga, Opere 178)

This process is "grandioso" only when viewed from a distance ("da lontano"). On closer analysis what may seem a virtuous undertaking is only a vehicle for vice and points to the corruption that underlies these grandiose results:

le irrequietudini, le avidità, l'egoismo, tutte le passioni, tutti i vizi . . . tutte le debolezze ... tutte le contraddizioni. (Verga, Opere 178)

Like Gramigna's "mala pianta," the "fiumana" of progress ("Dalla ricerca del benessere materiale alle più elevate ambizioni") sweeps away everyone without discrimination including those who at first sight may appear to be the makers of history. From I Malavoglia to Mastro don Gesualdo, to the Duchessa di Leyra, to the Onorevole Scipione to L'Uomo di Lusso, all the main characters of these novels are losers, "vinti." Like Peppa, they are all swept away by their desires and drowned, "altrettanti vinti che la corrente ha deposti sulla riva, dopo averli travolti e annegati, ciascuno colle stimmate del suo peccato, che avrebbero dovuto essere lo sfolgorare della sua virtù" (Verga, Opere 178).

In "L'amante di Gramigna," and in other stories of Vita dei Campi, Verga deals with human passions, namely, love, fear, respect, honor. In the novels he takes up other and more grandiose passions like the desire for well-being, ambi- 
tion, greed. In all these cases the process in which the characters are caught is the same. Whether the desire is for a "real" man or, simply, for a more comfortable living, these characters are caught in a process in which only apparently are they protagonists who have control over their actions. Whether the process is called "gramigna," "malpelo" or "fiumana," these characters are caught in a mechanism which sweeps them away on the shore of their inevitable catastrophe. In all cases we are confronted with a process which is linguistic in essence since the "mysterious" process of human passions that Verga represents is not separate from the language that triggers it, sustains it and, finally, sweeps these characters away. To have portrayed this link between language and passion is what is revolutionary in Verga's verismo and stands as his great contribution to the science of the human heart.

Although "Rosso Malpelo," or any of his works could be used to explain Verga's poetics, in principle, it is clear from the way they have been read, traditionally, that it has not been equally possible to determine the relevant narrative structures that single them out. This is because, as Verga well knew, only an "abbozzo di storia," without the trimmings and trappings of a unified and complete narrative, can expose the essential and vital mechanism that underlies it and makes it work. For this reason, "L'amante di Gramigna" should rightly be considered paradigmatic not only of Vita dei Campi but of Verga's writing in general, as Verga had intended.

As for Verga who is equally caught within this process, all he can do is stand back and portray this "mysterious" process objectively and dispassionately, without judging it.

Chi osserva questo spettacolo non ha il diritto di giudicarlo . . è già molto se riesce a trarsi un istante fuori del campo della lotta per studiarla senza passione, e rendere la scena nettamente, coi colori adatti, tale da dare la rappresentazione della realtà com'è stata, o come avrebbe dovuto essere (Verga, Opere 179, my italics)

Whether we call this process "irony" or "verismo," as traditional criticism has it, so be it, but we should not let a definition of verismo, as we traditionally understand it, dictate the way we read Verga. The dangers of "hearsay," even in the field of literary criticism, are clearly too dire for us to choose to ignore its warnings.

\section{University of Alberta}

\section{NOTES}

1 The short story was initially published as "L'Amante di Raja" in the February 1880 issue of Rivista minima di scienze, lettere ed arti. In the same year it was included in the collection of stories Vita dei campi.

2 This attitude is also echoed by Cecchetti who believes, however, that the letter can point to many common characteristics of Verga's prose (Cecchetti $32 \mathrm{ff}$.). 
3 The importance of the name is evident in Verga's decision to change the bandit's name from Raja to Gramigna.

\section{WORKS CITED}

Bàrberi Squarotti, Giorgio. Giovanni Verga. Le finzioni dietro il verismo. Palermo: S.F. Flaccovio, 1982.

Cecchetti, Giovanni. Il Verga maggiore. Sette studi. Firenze: La Nuova Italia, 1968.

Croce, Benedetto. La letteratura della Nuova Italia. Vol. 3. Bari: Laterza, 1956.

Debenedetti, Giacomo. Verga e il Naluralismo. Milano: Garzanti, 1976.

Lucente, Gregory. Beautiful Fables. Self-consciousness in Italian Narrative from Manzoni to Calvino. Baltimore and London: The Johns Hopkins UP, 1986.

Luperini, Romano. Verga e le strutture narrative del realismo. Saggio su "Rosso Malpelo." Padova: Liviana Editrice, 1976.

Verga, Giovanni. Le Novelle di Giovanni Verga. Ed. Gino Tellini. 2 vols. Roma: Salerno, 1970. . Opere. Milano, Napoli: Ricciardi, 1961. 